\title{
Metabolic syndrome in chronic hepatitis C infection: does it still matter in the era of directly acting antiviral therapy?
}

This article was published in the following Dove Press journal:

Hepatic Medicine: Evidence and Research

3 December 2014

Number of times this article has been viewed

TR Lim

Centre for Liver Research and NIHR Biomedical Research Unit in Liver Disease, University of Birmingham and Liver and Hepatobiliary Unit, Queen Elizabeth Hospital Birmingham, UK
Correspondence: TR Lim

School of Immunity and Infection, Biomedical Research Unit, University of Birmingham, Edgbaston, Birmingham BI5 2TT, UK

Email t.r.lim@bham.ac.uk
Abstract: Metabolic syndrome is prevalent in patients with hepatitis $\mathrm{C}$ virus (HCV) infection. Given the pandemic spread of HCV infection and metabolic syndrome, the burden of their interaction is a major public health issue. The presence of metabolic syndrome accelerates the progression of liver disease in patients with HCV infection. New drug development in HCV has seen an unprecedented rise in the last year, which resulted in better efficacy, better tolerance, and a shorter treatment duration. This review describes the underlying mechanisms and clinical effects of metabolic syndrome in HCV infection, as well as their importance in the era of new directly acting antiviral therapy.

Keywords: HCV, genotype 3, metabolic syndrome, steatosis, directly acting antiviral agents

\section{Introduction}

There are approximately 170 million people in the world infected with hepatitis $\mathrm{C}$ virus (HCV) and 350,000 deaths each year are caused by HCV infection. ${ }^{1}$ The prevalence of $\mathrm{HCV}$ infection in the United Kingdom is estimated to be $0.54 \%$ or 218,000 people. HCV infection is associated with the development of insulin resistance, diabetes mellitus, and hepatic steatosis. ${ }^{2-5}$ Epidemiological studies have demonstrated that hepatic steatosis occurs more frequently in patients with HCV infection $(55 \%)$ than in the general population $(20 \%-30 \%)$ in the Western world. ${ }^{6-8}$ The macrovesicular steatosis present in patients with HCV infection is also distributed in the periportal areas rather than the centrilobular region which is more commonly seen in non-alcoholic fatty liver disease, ${ }^{9}$ indicating that HCV may be directly inducing steatosis rather than being an unrelated finding. It has been suggested that there are two main types of steatosis. The first type is thought to be a direct viral effect, which develops in the absence of "metabolic syndrome" (obesity, hyperlipidaemia, and insulin resistance), and is more prevalent in genotypes 2 and 3 HCV infections. ${ }^{10,11}$ The second type is associated with metabolic syndrome, and is prevalent in genotype $1 \mathrm{HCV}$ infection. ${ }^{12}$ These two forms of steatosis can coexist in patients with genotype 3 infections.

Insulin resistance linked to $\mathrm{HCV}$ infection was first reported by Allison et al, ${ }^{13}$ who observed that type 2 diabetes mellitus was more prevalent in patients with $\mathrm{HCV}$ associated cirrhosis compared to other causes of cirrhosis. Following that, several other cross-sectional studies have also linked HCV and insulin resistance. ${ }^{2,14-16}$ Insulin resistance, evaluated through the homeostasis model assessment (HOMA-IR), can be genotype specific, although the different studies are not consensual in that regard. 
Some studies have shown that insulin resistance is more prevalent in genotypes 1 and 4, as compared to genotypes 2 and $3 \mathrm{HCV}$ infections. ${ }^{17,18}$

Treatment for hepatitis $\mathrm{C}$ has evolved rapidly over the last few years. In 2013, the Food and Drug Administration (FDA) approved the use of simeprevir and sofosbuvir for the treatment of hepatitis $\mathrm{C}$ infection, which will improve treatment outcomes significantly. This review focuses on the pathophysiology and the relevance of metabolic syndrome in hepatitis $\mathrm{C}$ infection in the era of these new directly acting antiviral therapies.

\section{Pathogenesis of metabolic syndrome in HCV infection}

\section{Steatosis}

The close association of $\mathrm{HCV}$ and steatosis is evident from in vitro studies demonstrating that HCV hijacks the lipid-producing machinery of hepatocytes for its benefit. ${ }^{19,20}$ The HCV core protein has been studied at length in both cell culture and in transgenic mice. Intracellular lipid buildup seems to occur when $\mathrm{HCV}$ core protein is highly expressed. ${ }^{20}$ The core protein localizes at the surface of lipid droplets within the cytoplasm in cells transfected with $\mathrm{HCV}^{21}$ Other studies have shown that the core protein interacts with the cell machinery involved in lipid metabolism such as apolipoproteins A1 and $\mathrm{A} 2$, which are involved in triglyceride accumulation and storage in the hepatocytes.$^{20} \mathrm{HCV}$ core protein also upregulates sterol regulatory element binding protein 1c (SREBP-1c), a transcriptional factor that mediates several lipogenic genes in lipid metabolism ${ }^{22-24}$ as well as binds to DNA-binding domain of retinoid X receptor alpha (RXRa), a nuclear receptor that regulates several genes involved in cellular lipids synthesis, thus promoting de novo lipogenesis. ${ }^{25}$ Furthermore, it inhibits microsomal triglyceride transfer protein (MTP) activity. As this is a rate-limiting enzyme playing a key role in the very low density lipoproteins (VLDL) assembly, the direct and likely consequence of its inactivation is accumulation of unsecreted triglycerides, hence steatosis. ${ }^{26}$ Accumulation of core protein in mitochondria can impair electron transport and thus increase the production of reactive oxygen species (ROS). ${ }^{27}$ Oxidative stress leads to peroxidation of lipids and structural proteins, disturbing the cellular traffic apparatus and VLDL secretion. ${ }^{28}$ Recent studies have demonstrated a diminished peroxisome proliferator-activated receptor alpha (PPAR $\alpha$ ) expression induced by HCV core protein. PPAR $\alpha$ regulates the transcription of mitochondrial carnitine palmitoyl acyl-CoA transferase 1 alpha (CPT1A), which is a rate-limiting enzyme in mitochondrial beta-oxidation mediating the entry of fatty acids into the mitochondria. ${ }^{29,30}$

\section{Insulin resistance}

Insulin binding to the insulin receptor results in phosphorylation of the receptor and tyrosine phosphorylation of intracellular insulin receptor substrate (IRS) proteins, mainly IRS-1 and IRS-2. This activates two major cellular signaling pathways, the phosphoinositide-3 kinase (PI3K)/Akt and the Ras/ mitogen-activated protein kinase (MAPK) pathways. ${ }^{31} \mathrm{HCV}$ directly perturbs insulin signaling by modulating the insulin receptor and IRS-1 and subsequently downregulating PI3K. ${ }^{32}$ Knockout of the IRS-1 and -2 genes in murine models induces insulin resistance and results in hyperinsulinaemia, thus indicating the importance of IRS- 1 and -2 as mediators of insulin action. ${ }^{33,34}$ The effects of HCV core protein on the expression of IRS- 1 and -2 were investigated in 357 patients with chronic liver disease, and $\mathrm{HCV}$ core protein in serum was associated with insulin resistance and decreased levels of these proteins. ${ }^{35}$ It is thought that $\mathrm{HCV}$ core protein can also induce insulin resistance via the upregulation of suppressor of cytokine signaling-3 (SOCS-3), SOCS-7, and proteasome-activator 28-gamma (PA28 $\gamma$ ), and downregulation of peroxisome proliferator-activated receptor-gamma (PPAR $\gamma$ ). ${ }^{35,36}$ Activation of the mammalian target of rapamycin (mTOR) downstream of the PI3K/Akt pathway has also emerged as a critical event in rendering IRS unresponsive to insulin. ${ }^{37}$ Lastly, tumor necrosis factor- $\alpha$ (TNF- $\alpha$ ) also induces insulin resistance in $\mathrm{HCV}$ infection by impairing insulin signaling through serine phosphorylation of IRS-1 and -2, thus downregulating glucose transporter-2 and -4 (Glut2/Glut4) gene expression. ${ }^{38}$

\section{Clinical consequences of metabolic disease in HCV infection Hepatic fibrosis}

A close relationship between insulin resistance and liver fibrosis has been shown in many studies..$^{39,40}$ New onset diabetes is a poor predictor in patients with $\mathrm{HCV}$ infection without cirrhosis. In this group, the cumulative incidence of cirrhosis and decompensated cirrhosis was significantly higher in patients with diabetes than those without. ${ }^{41}$ Regardless of the viral genotype and severity of liver damage, serum insulin concentrations and homeostasis model assessment of insulin resistance (HOMA-IR) index scores increase with the severity of hepatic fibrosis. ${ }^{18,42}$ It is believed that hyperinsulinemia and hyperglycemia directly stimulate hepatic stellate cells, leading to activation of connective tissue growth factor and subsequent accumulation of extracellular matrix. ${ }^{43,44}$ Most retrospective studies have shown positive correlations between the severity of steatosis and 
stage of hepatic fibrosis. ${ }^{45}$ It is difficult to ascertain whether the two types of hepatic steatosis contribute equally to the overall disease progression in patients with HCV infection. The majority of studies have not separated the two types of steatosis when examining these questions.

\section{Hepatocellular carcinoma}

It is also well recognized that the presence of metabolic disturbance in patients infected with $\mathrm{HCV}$ accelerates the development of hepatocellular carcinoma. ${ }^{46-49}$ Elkrief et $\mathrm{al}^{50}$ followed 348 cirrhotic patients with $\mathrm{HCV}$ infection treated in hospital between 2006 and 2008. At baseline, 29\% of the patients had diabetes. This was independently associated with the development of ascites, bacterial infections, and hepatocellular carcinoma. The underlying mechanisms linking insulin resistance and hepatocellular carcinoma remain to be elucidated. Hypotheses are based on the mitogenic role of insulin on cell proliferation and its binding on insulin-like growth factor-1 receptors, resulting in the activation of downstream cascade of intracellular responses. ${ }^{51}$ Patients infected with $\mathrm{HCV}$ also seem to have poorer quality of life, ${ }^{52}$ increased liver and cardiac mortality, as well as all-cause mortality. ${ }^{53}$

\section{Effect of metabolic disease on treatment outcomes Interferon-based therapy}

The presence of hepatic steatosis and insulin resistance reduces the likelihood of achieving sustained virological response (SVR) with standard pegylated interferon (peg-IFN) and ribavirin therapy in $\mathrm{HCV}$ patients. ${ }^{54-59}$ Steatosis is also associated with higher rates of relapse, irrespective of viral load, in patients with genotype $3 \mathrm{HCV}$ infections. ${ }^{45,54,60,61}$ An increase in HOMA-IR index score is associated with reduced early virological response (EVR) and SVR rates in genotypes 1 to $3 \mathrm{HCV}$ infections. ${ }^{58,63}$

In contrast to peg-IFN/ribavirin dual therapy, metabolic factors and insulin resistance do not seem to have a significant effect on telaprevir-based treatment efficacy. In treatmentnaïve patients with genotype $1 \mathrm{HCV}$ infection receiving triple therapy consisting of peg-IFN, ribavirin and telaprevir, HOMA-IR values were not predictive of virological response rates, even though SVRs appeared to be associated with improved insulin sensitivity. ${ }^{64}$ The lack of association between baseline HOMA-IR and treatment outcomes with telaprevir-based therapy is also seen in treatment-experienced HCV patients in the REALIZE trial. ${ }^{65}$

If lipid metabolism and metabolic syndrome are linked to $\mathrm{HCV}$ infection, lipid modification represents a novel target for therapeutic intervention in HCV infection. Studies looking at the effect of insulin sensitizers such as metformin and thiazolidinediones in improving treatment outcomes have been disappointing. Data from studies looking at peroxisome proliferator-activated receptor-gamma (PPAR- $\gamma$ ) agonist pioglitazone therapy with peg-IFN and ribarivin in $\mathrm{HCV}$ patients have failed to show increased SVR. ${ }^{66,67}$ Other studies have shown that 3-hydroxy-3-methylglutaryl CoA (HMG CoA) reductase inhibitors, when used as monotherapy, are able to inhibit de novo lipogenesis and HCV replication in vitro, ${ }^{68}$ but these effects were not replicated in human studies. ${ }^{69,70}$ However, when used in combination with peg-IFN and ribavirin, statin does seem to improve virological response to dual therapy. ${ }^{71-74}$ Their role for use in conjunction with directly acting antiviral therapy has not been evaluated.

\section{Interferon-free therapy}

Treatment of HCV infection is transitioning from IFN-based to IFN-free regimens composed of directly acting antiviral agents (DAAs), which result in higher rates of SVR. The association between baseline metabolic characteristics and treatment outcome during IFN-free DAA treatment has not been fully elucidated. One recent study looked at the impact of HCV infection on host metabolism and its association with treatment outcome with sofosbuvir and ribavirin in genotype 1 $\mathrm{HCV}$ patients. Clearance of $\mathrm{HCV}$ using this combination results in rapid changes in peripheral and intrahepatic metabolic pathways, irrespective of treatment outcome, implicating a direct effect of HCV replication on lipid homeostasis. Importantly, lower baseline serum low-density lipoprotein (LDL) and lower expression of fatty acid metabolism and lipid transport genes at the end of treatment were associated with relapse, suggesting the relevance of host metabolism on treatment outcome with this DAA combination in genotype 1 $\mathrm{HCV}$ infection. ${ }^{75}$ In a Phase Ib placebo-controlled study, the use of danoprevir monotherapy, a second-generation protease inhibitor, seems to restore insulin sensitivity in treatmentnaïve patients and previous nonresponders with genotype 1 $\mathrm{HCV}$ infection. ${ }^{76}$ These results are not surprising, as one would expect a drop in viral load to improve insulin resistance. Its effect on insulin sensitivity and treatment outcomes when used in combination with other antiviral treatment remains to be determined in the era of IFN-free therapy.

Both the first and next generations of DAAs appear to be less effective against genotype 3 infections. ${ }^{77}$ Hepatic steatosis may be, at least in part, responsible for the persistently low rates of SVR associated with genotype 3. It may be that intrahepatic fat sequestration by the replicating virus reduces 
access of DAAs, thereby reducing the efficacy of these drugs. Most observations on metabolic changes and dyslipidemia associated with the use of DAAs focused on genotype 1 $\mathrm{HCV}$ infections. Therefore, further work to examine the mechanisms underlying treatment failure with genotype 3 is urgently required.

\section{Summary}

The landscape of therapy for HCV infections is changing rapidly. The tremendous improvement in SVR rates in genotypes 1 and 2 has rendered genotype $3 \mathrm{HCV}$ infection the major challenge with DAA, as it continues to afflict a large population of patients. Furthermore, the prohibitive costs of such therapies may limit their use in patients in developing countries where most of the HCV infections exist. For these reasons, HCV genotype 3 has emerged as a priority for future therapy development. Its unique link to insulin resistance and its highly pro-steatogenic effect in the liver suggest that understanding of the pathology and mechanism of metabolic syndrome in HCV infection is still paramount.

\section{Disclosure}

The author reports no conflicts of interest in this work.

\section{References}

1. Perz JF, Armstrong GL, Farrington LA, Hutin YJ, Bell BP. The contributions of hepatitis $B$ virus and hepatitis $C$ virus infections to cirrhosis and primary liver cancer worldwide. J Hepatol. 2006;45(4): 529-538.

2. Stepanova M, Lam B, Younossi Y, Srishord MK, Younossi ZM. Association of hepatitis $\mathrm{C}$ with insulin resistance and type 2 diabetes in US general population: the impact of the epidemic of obesity. JViral Hepat. 2012;19(5):341-345.

3. White DL, Ratziu V, El-Serag HB. Hepatitis C infection and risk of diabetes: a systematic review and meta-analysis. J Hepatol. 2008;49(5): 831-844.

4. Negro F, Alaei M. Hepatitis C virus and type 2 diabetes. World J Gastroenterol. 2009;15(13):1537-1547.

5. Negro F, Sanyal AJ. Hepatitis C virus, steatosis and lipid abnormalities: clinical and pathogenic data. Liver Int. 2009;29(Suppl 2):26-37.

6. Clark JM, Brancati FL, Diehl AM. Nonalcoholic fatty liver disease. Gastroenterology. 2002;122(6):1649-1657.

7. Rubbia-Brandt L, Fabris P, Paganin S, et al. Steatosis affects chronic hepatitis C progression in a genotype specific way. Gut. 2004;53(3): 406-412.

8. Monto A, Alonzo J, Watson JJ, Grunfeld C, Wtight TL, et al. Steatosis in chronic hepatitis $\mathrm{C}$ : relative contributions of obesity, diabetes mellitus, and alcohol. Hepatology. 2002;36(3):729-36.

9. Zaitoun AM, Al Mardini H, Awad S, Ukabam S, Makadisi S, Record CO. Quantitative assessment of fibrosis and steatosis in liver biopsies from patients with chronic hepatitis C. J Clin Pathol. 2001;54(6):461-465.

10. Cross TJ, Rashid MM, Berry PA, Harrison PM. The importance of steatosis in chronic hepatitis $\mathrm{C}$ infection and its management: a review. Hepatol Res. 2010;40(3):237-247.

11. Milner KL, van der Poorten D, Trenell M, et al. Chronic hepatitis C is associated with peripheral rather than hepatic insulin resistance. Gastroenterology. 2010;138(3):932-941. e1-e3.
12. Vanni E, Abate ML, Gentilcore E, et al. Sites and mechanisms of insulin resistance in nonobese, nondiabetic patients with chronic hepatitis $\mathrm{C}$. Hepatology. 2009;50(3):697-706.

13. Allison ME, Wreghitt T, Palmer CR, Alexander GJ. Evidence for a link between hepatitis $\mathrm{C}$ virus infection and diabetes mellitus in a cirrhotic population. J Hepatol. 1994;21(6):1135-1139.

14. Oliveira LP, Jesus RP, Boulhosa RS, Mendes CM, Lyra AC, Lyra LG. Metabolic syndrome in patients with chronic hepatitis $C$ virus genotype 1 infection who do not have obesity or type 2 diabetes. Clinics (Sao Paulo). 2012;67(3):219-223.

15. Souza AF, Pace FH, Chebil JM, Ferreria LE. Insulin resistance in nondiabetic patients with chronic hepatitis C: what does it mean? Arq Bras Endocrinol Metabol. 2011;55(6):412-418.

16. Ahmed AM, Hassan MS, Abd-Elsayed A, Hassan H, Hassanain AF, Helmy A. Insulin resistance, steatosis, and fibrosis in Egyptian patients with chronic Hepatitis C virus infection. Saudi J Gastroenterol. 2011;17(4):245-251.

17. Moucari R, Asselah T, Cazals-Hatem D, et al. Insulin resistance in chronic hepatitis $C$ : association with genotypes 1 and 4, serum HCV RNA level, and liver fibrosis. Gastroenterology. 2008;134(2):416-423.

18. Hui JM, Sud A, Farrell GC, et al. Insulin resistance is associated with chronic hepatitis $\mathrm{C}$ virus infection and fibrosis progression [corrected]. Gastroenterology. 2003;125(6):1695-1704.

19. Shi ST, Polyak SJ, Tu H, Taylor DR, Gretch DR, Lai MM. Hepatitis C virus NS5A colocalizes with the core protein on lipid droplets and interacts with apolipoproteins. Virology. 2002;292(2):198-210.

20. Barba G, Harper F, Harada T, et al. Hepatitis C virus core protein shows a cytoplasmic localization and associates to cellular lipid storage droplets. Proc Natl Acad Sci U S A. 1997;94(4):1200-1205.

21. Moradpour D, Englert C, Wakita T, Wands JR. Characterization of cell lines allowing tightly regulated expression of hepatitis $\mathrm{C}$ virus core protein. Virology. 1996;222(1):51-63.

22. Su AI, Pezacki JP, Wodicka L, et al. Genomic analysis of the host response to hepatitis C virus infection. Proc Natl Acad Sci USA. 2002; 99(24):15669-15674.

23. Kim KH, Hong SP, Kim K, Park MJ, Kim KJ, Cheong J. HCV core protein induces hepatic lipid accumulation by activating SREBP1 and PPARgamma. Biochem Biophys Res Commun. 2007;355(4): 883-888.

24. Jackel-Cram C, Babiuk LA, Liu Q. Up-regulation of fatty acid synthase promoter by hepatitis $\mathrm{C}$ virus core protein: genotype- 3 a core has a stronger effect than genotype-1b core. J Hepatol. 2007;46(6):999-1008.

25. Tsutsumi T, Suzuki T, Shimoike T, et al. Interaction of hepatitis $C$ virus core protein with retinoid $\mathrm{X}$ receptor alpha modulates its transcriptional activity. Hepatology. 2002;35(4):937-946.

26. Perlemuter G, Sabile A, Letteron $P$, et al. Hepatitis $C$ virus core protein inhibits microsomal triglyceride transfer protein activity and very low density lipoprotein secretion: a model of viral-related steatosis. FASEB J. 2002;16(2):185-194.

27. Okuda M, Li K, Showalter LA, et al. Mitochondrial injury, oxidative stress, and antioxidant gene expression are induced by hepatitis $\mathrm{C}$ virus core protein. Gastroenterology. 2002;122(2):366-375.

28. Negro F. Mechanisms and significance of liver steatosis in hepatitis C virus infection. World J Gastroenterol. 2006;12(42):6756-6765.

29. Dharancy S, Malapel M, Perlemuter G, et al. Impaired expression of the peroxisome proliferator-activated receptor alpha during hepatitis C virus infection. Gastroenterology. 2005;128(2):334-342.

30. Cheng Y, Dharancy S, Malapel M, Desreumaux P. Hepatitis C virus infection down-regulates the expression of peroxisome proliferator-activated receptor alpha and carnitine palmitoyl acyl-CoA transferase 1A. World J Gastroenterol. 2005;11(48):7591-7596.

31. Sesti G. Pathophysiology of insulin resistance. Best Pract Res Clin Endocrinol Metab. 2006;20(4):665-679.

32. Aytug S, Reich D, Sapiro LE, Bernstein D, Begum N. Impaired IRS-1/PI3-kinase signaling in patients with HCV: a mechanism for increased prevalence of type 2 diabetes. Hepatology. 2003;38(6): 1384-1392. 
33. Araki E, Lipes MA, Patti ME, et al. Alternative pathway of insulin signalling in mice with targeted disruption of the IRS-1 gene. Nature. 1994;372(6502):186-190.

34. Withers DJ, Gutierrez JS, Towery H, et al. Disruption of IRS-2 causes type 2 diabetes in mice. Nature. 1998;391(6670):900-904.

35. Kawaguchi T, Yoshida T, Harada M, et al. Hepatitis C virus down-regulates insulin receptor substrates 1 and 2 through up-regulation of suppressor of cytokine signaling 3. Am J Pathol. 2004;165(5): 1499-1508.

36. Pazienza V, Clément S, Pugnale P, et al. The hepatitis C virus core protein of genotypes $3 \mathrm{a}$ and $1 \mathrm{~b}$ downregulates insulin receptor substrate 1 through genotype-specific mechanisms. Hepatology. 2007;45(5): 1164-1171.

37. Wang X, Proud CG. The mTOR pathway in the control of protein synthesis. Physiology (Bethesda). 2006;21:362-369.

38. Im SS, Kwon SK, Kim TH, Kim HI, Ahn YH. Regulation of glucose transporter type 4 isoform gene expression in muscle and adipocytes. IUBMB Life. 2007;59(3):134-145.

39. Sheikh MY, Choi J, Qadri I, Freidman JE, Sanyal AJ. Hepatitis C virus infection: molecular pathways to metabolic syndrome. Hepatology. 2008;47(6):2127-2133.

40. Ait-Goughoulte M, Banarjee A, Meyer K, et al. Hepatitis C virus core protein interacts with fibrinogen-beta and attenuates cytokine stimulated acute-phase response. Hepatology. 2010;51(5):1505-1513.

41. Huang YW, YangSS, Fu SC, et al. Increased risk of cirrhosis and its decompensation in chronic hepatitis $\mathrm{C}$ patients with new-onset diabetes: a nationwide cohort study. Hepatology. 2014;60(3):807-814.

42. Petta $\mathrm{S}$, Cammà $\mathrm{C}, \mathrm{Di}$ Marco $\mathrm{V}$, et al. Insulin resistance and diabetes increase fibrosis in the liver of patients with genotype $1 \mathrm{HCV}$ infection Am J Gastroenterol. 2008;103(5):1136-1144.

43. Hsu CS, Liu CH, Liu CJ, et al. Association of metabolic profiles with hepatic fibrosis in chronic hepatitis $\mathrm{C}$ patients with genotype 1 or 2 infection. J Gastroenterol Hepatol. 2010;25(5):970-977.

44. Taura N, Ichikawa T, Hamasaki K, et al. Association between liver fibrosis and insulin sensitivity in chronic hepatitis C patients. Am J Gastroenterol. 2006;101(12):2752-2759.

45. Patton HM, Patel K, Behling C, et al. The impact of steatosis on disease progression and early and sustained treatment response in chronic hepatitis C patients. J Hepatol. 2004;40(3):484-490.

46. Lai SW, Chen PC, Liao KCF, Muo CH, Lin CC, Sung FC. Risk of hepatocellular carcinoma in diabetic patients and risk reduction associated with anti-diabetic therapy: a population-based cohort study. Am J Gastroenterol. 2012;107(1):46-52.

47. Salmon D, Bani-Sadr F, Loko MA, et al. Insulin resistance is associated with a higher risk of hepatocellular carcinoma in cirrhotic $\mathrm{HIV} / \mathrm{HCV}$ co-infected patients: results from ANRS CO13 HEPAVIH. J Hepatol. 2012;56(4):862-868.

48. Younossi ZM, McCullough AJ. Metabolic syndrome, non-alcoholic fatty liver disease and hepatitis $\mathrm{C}$ virus: impact on disease progression and treatment response. Liver Int. 2009;29(Suppl 2):3-12.

49. Patel K, Thompson AJ, Chuang WL, et al. Insulin resistance is independently associated with significant hepatic fibrosis in Asian chronic hepatitis C genotype 2 or 3 patients. J Gastroenterol Hepatol. 201;26(7): 1182-1188.

50. Elkrief L, Chouinard P, Bendersky N, et al. Diabetes mellitus is an independent prognostic factor for major liver-related outcomes in patients with cirrhosis and chronic hepatitis C. Hepatology. 2014;60(3): 823-831.

51. Sandhu MS, Dunger, Giovannucci EL. Insulin, insulin-like growth factor-I (IGF-I), IGF binding proteins, their biologic interactions, and colorectal cancer. J Natl Cancer Inst. 2002;94(13):972-980.

52. Kuwashiro T, Mizuta T, Kawaguchi Y, et al. Impairment of healthrelated quality of life in patients with chronic hepatitis $\mathrm{C}$ is associated with insulin resistance. J Gastroenterol. 2014;49(2):317-323.

53. Guiltinan AM, Kaidarova Z, Custer B, et al. Increased all-cause, liver, and cardiac mortality among hepatitis $\mathrm{C}$ virus-seropositive blood donors. Am J Epidemiol. 2008;167(6):743-750.
54. Restivo L, Zampino R, Guerrera B, Ruggiero L, Adinolfi LE. Steatosis is the predictor of relapse in HCV genotype 3- but not 2-infected patients treated with 12 weeks of pegylated interferon-alpha-2a plus ribavirin and RVR. J Viral Hepat. 201219(5):346-352.

55. Romero-Gomez M, Del mar Viloria M, Andrade RJ, et al. Insulin resistance impairs sustained response rate to peginterferon plus ribavirin in chronic hepatitis C patients. Gastroenterology. 2005;128(3): 636-641.

56. Brandman D, Bacchetti P, Ayala CE, Maher JJ, Khalil M. Impact of insulin resistance on $\mathrm{HCV}$ treatment response and impact of $\mathrm{HCV}$ treatment on insulin sensitivity using direct measurements of insulin action. Diabetes Care. 2012;35(5):1090-1094.

57. Aziz H, Gill U, Raza A, Gill ML. Metabolic syndrome is associated with poor treatment response to antiviral therapy in chronic hepatitis C genotype 3 patients. Eur J Gastroenterol Hepatol. 2014;26(5): 538-543.

58. Deltenre P, Louvet A, Lemoine M, et al. Impact of insulin resistance on sustained response in HCV patients treated with pegylated interferon and ribavirin: a meta-analysis. J Hepatol. 2011;55(6):1187-1194.

59. D'Souza R, Sabin CA, Foster GR. Insulin resistance plays a significant role in liver fibrosis in chronic hepatitis $\mathrm{C}$ and in the response to antiviral therapy. Am J Gastroenterol. 2005;100(7):1509-1515.

60. Rafi H, Kabbaj N, Salihoun M, et al. Influence of steatosis on progression of fibrosis and virological response in chronic hepatitis $\mathrm{C}$ cases. Arab J Gastroenterol. 2011;12(3):136-138.

61. Harrison SA, Brunt EM, Qazi RA, et al. Effect of significant histologic steatosis or steatohepatitis on response to antiviral therapy in patients with chronic hepatitis C. Clin Gastroenterol Hepatol. 2005;3(6): 604-609.

62. Bortoletto G, Scribano L, Realdon S, et al. Hyperinsulinaemia reduces the 24-h virological response to PEG-interferon therapy in patients with chronic hepatitis C and insulin resistance. J Viral Hepat. 2010;17(7): 475-480.

63. Poustchi H, Negro F, Hui J, et al. Insulin resistance and response to therapy in patients infected with chronic hepatitis $\mathrm{C}$ virus genotypes 2 and 3. J Hepatol. 2008;48(1):28-34.

64. Serfaty L, Forns X, Goeser T, et al. Insulin resistance and response to telaprevir plus peginterferon alpha and ribavirin in treatment-naive patients infected with HCV genotype 1. Gut. 2012;61(10):1473-1480.

65. Younossi Z, Negro F, Serfaty L, et al. Homeostasis model assessment of insulin resistance does not seem to predict response to telaprevir in chronic hepatitis C in the REALIZE trial. Hepatology. 2013;58(6): 1897-1906.

66. Overbeck K, Genne D, Golay A, et al. Pioglitazone in chronic hepatitis $\mathrm{C}$ not responding to pegylated interferon-alpha and ribavirin. $J$ Hepatol. 2008;49(2):295-298.

67. Harrison SA, Hamzeh FM, Han J, Pandya PK, Sheikh MY, Vierling JM. Chronic hepatitis $\mathrm{C}$ genotype 1 patients with insulin resistance treated with pioglitazone and peginterferon alpha-2a plus ribavirin. Hepatology. 2012;56(2):464-473.

68. Ikeda M, Abe K, Yamada M, Dansako H, Naka K, Kato N. Different anti-HCV profiles of statins and their potential for combination therapy with interferon. Hepatology. 2006;44(1):117-125.

69. O’Leary JG, Chan JL, McMahon CM, Chung RT. Atorvastatin does not exhibit antiviral activity against $\mathrm{HCV}$ at conventional doses: a pilot clinical trial. Hepatology. 2007;45(4):895-898.

70. Milazzo L, Meroni L, Galazzi M, et al. Does fluvastatin favour HCV replication in vivo? A pilot study on HIV-HCV coinfected patients. J Viral Hepat. 2009;16(7):479-484.

71. Harrison SA, Rossaro L, Hu KQ, et al. Serum cholesterol and statin use predict virological response to peginterferon and ribavirin therapy. Hepatology. 2010;52(3):864-874.

72. Rao GA, Pandya PK. Statin therapy improves sustained virologic response among diabetic patients with chronic hepatitis C. Gastroenterology. 2011;140(1):144-152.

73. Bader T, Fazili J, Madhoun M, et al. Fluvastatin inhibits hepatitis C replication in humans. Am J Gastroenterol. 2008;103(6):1383-1389. 
74. Kondo C, Atsukawa M, Tsubota A, et al. An open-label randomized controlled study of pegylated interferon/ribavirin combination therapy for chronic hepatitis $\mathrm{C}$ with versus without fluvastatin. J Viral Hepat. 2012;19(9):615-622.

75. Meissner EG, Lee YJ, Osinusi A, et al. Effect of sofosbuvir and ribavirin treatment on peripheral and hepatic lipid metabolism in chronic HCV, genotype-1 infected patients. Hepatology. Epub September 9, 2014.
76. Moucari R, Forestier N, Larrey D, et al. Danoprevir, an HCV NS3/4A protease inhibitor, improves insulin sensitivity in patients with genotype 1 chronic hepatitis C. Gut. 2010;59(12):1694-1698.

77. Pawlotsky JM. New hepatitis C therapies: the toolbox, strategies, and challenges. Gastroenterology. 2014;146(5):1176-1192.

\section{Publish your work in this journal}

Hepatic Medicine: Evidence and Research is an international, peerreviewed, open access journal covering all aspects of adult and pediatric hepatology in the clinic and laboratory including the following topics: Pathology, pathophysiology of hepatic disease; Investigation and treatment of hepatic disease; Pharmacology of drugs used for the treatment of hepatic disease. Issues of patient safety and quality of care will also be considered. The manuscript management system is completely online and includes a very quick and fair peer-review system, which is all easy to use. Visit http://www.dovepress.com/ testimonials.php to read real quotes from published authors.

Submit your manuscript here: http://www.dovepress.com/hepatic-medicine-evidence-and-research-journal 